\title{
THE INTERPLAY OF TECHNOLOGICAL INNOVATION AND BUSINESS MODEL INNOVATION TOWARD COMPANY PERFORMANCE
}

\author{
Selma Smajlovic* \\ Bahrija Umihanic ${ }^{* * *}$ \\ Lejla Turulja***
}

Received: 13. 6. 2019

Preliminary communication

Accepted: 19. 11. 2019

UDC: 005.61:330.341.1

DOI: https://doi.org/10.30924/mjcmi.24.2.5

\begin{abstract}
This study aims to clarify the relation between technological innovation and business model innovation and their shared impact on the business success of medium and large enterprises. Drawing on the ResourceBased View, this paper offers a comprehensive research model that analyses the relationships between technological innovation and business model innovations and their impact on business success. Structural Equation Modelling is utilized for the analysis of a dataset collected in a Southeast European developing country among medium and large enterprises. The results show that technological innovation has a positive influence on business model innovation and that business model innovation positively impacts the success of a business. Finally, the results confirm the mediating role of business model innovation between technological innovation and company business success. This research adds to the existing literature by empirically investigating the relationship between technological innovation, business model innovation, and
\end{abstract}

company success identifying an antecedent role in the relationship between technological innovation and business model innovation.

Keywords: Technological innovation, business model innovation, business performance, $R B V, S E M$

\section{INTRODUCTION}

Increasing global competitiveness, shortening product lifecycles, increasing technological capability, and ever-changing customer preferences force firms to innovate (Baković \& Ledić-Purić, 2011), in order to achieve business success (Anning-Dorson, 2017). Innovative activities are usually perceived as a valuable capability of an organization, because they are needed to develop new business models, products and procedures, crucial to achieving sustainable

* Selma Smajlović, PhD., Senior Teaching Assisent, (corresponding author), University of Tuzla, Faculty of Economics, Bosnia and Herzegovina, Univerzitetska 8, BiH - 75000 Tuzla, Phone: +387 35320 820, E-mail: selma.smajlovic@untz.ba

** Bahrija Umihanić, Ph.D., Full Professor, University of Tuzla, Faculty of Economics, Bosnia and Herzegovina, Univerzitetska 8, BiH - 75000 Tuzla, Phone: +38735320 820, E-mail: bahrija.umihanic@untz.ba

*** "Lejla Turulja, Ph.D., Assistant Professor, School of Economics and Business Sarajevo, Bosnia and Herzegovina, Trg oslobodjenja - Alija Izetbegovic 1, Phone: +387 33275 970; E-mail: lejla.turulja@efsa.unsa.ba 
competitive advantage (Huang, Lai, Kao, \& Chen, 2012). The beginnings of the development of the theory of innovation and economic growth are connected with the analysis of Joseph Schumpeter (1934) who described the notion of innovation as the basis of technological progress and economic development in the sense of replacing old technologies with new ones, which he called "creative destruction". In his study, Schumpeter identified five types of innovation: introduction of new goods, new production methods, creation of new markets, discovery of new supply sources, and reorganization of industries (Schumpeter, 1934). Our research focuses on business model innovation and technological innovation, as well as their simultaneous influence on company's performance.

Innovation is company's potential to introduce new products/services or new production processes (Hult, Hurley, \& Knight, 2004; Pucihar, Lenart, Kljajić Borštnar, Vidmar, \& Marolt, 2019). The commercialization of innovation is not only a function of the innovation itself, but also of firm's business model development (Dmitriev, Simmons, Truong, Palmer \& Schneckenberg, 2014). The business model is complex because it is the entity of a series of organizational transactions and processes of the external environment, which connect the corporate strategy dimensions, technological capability, and company's process of innovation (Spieth, Schneckenberg, \& Ricart, 2014). Chesbrough \& Rosenbloom (2002b) relate the concept of business model to the literature on technology management and define it as "logical research that links technical potential to economic value" (p. 532), highlighting its role in connecting technology to market outcome. Chesbrough (2010) states that "mediocre technology driven by a large business model may be more valuable than large technology exploited by a mediocre business model" (p. 354).

Today's business environment and the accompanying effects, such as globalization, technological changes, emergence of the Internet and development of information technology (IT) significantly affect businesses, which is why companies are pushed continuously to adapt and change the way they do business (Turulja \& Bajgoric, 2018). In such an environment, the concept of the business model is highlighted as the critical phenomenon in modern companies' efforts to achieve organizational success, based on creating, capturing, and delivering value (Osterwalder, 2004) to end-users. Also, a large number of scholars and practitioners doubt the rationality of increased investments into innovation of products and processes, emphasizing that the realization of company's above-average success is the result of business model innovation (Chesbrough, 2010; Johnson, Christensen, \& Kagermann, 2008; Pohle \& Chapman, 2006). Following the findings of the importance of these two types of innovation for competitiveness and business success, companies have begun to realize that established business models do not guarantee long-term success in the context of accelerating business environmental dynamics (Desyllas \& Sako, 2013). Hence, managers are forced to continually innovate their business models, either as a reaction to the existing changes or as the proactive anticipation of changes. In the literature that addresses the issues of business model innovation, most researchers have so far paid attention to the conceptualization of business model innovation and its integral components (Heij at al., 2014; Spieth \&Schneider, 2016). However, most studies conducted so far are characterized by the qualitative approach (Wirtz, Göttel, \& 
Daiser, 2016). At the same time, there is a deficit in the research dealing with predictors and determinants of business model innovation, such as technological innovation and its relationship with business model innovation (Bashir, 2019; Hossain, 2017; Spieth et al., 2014).

The aim of this paper is to address a dilemma surrounding the antecedent role in the relationship between technological innovation and business model innovation. Specifically, some studies suggest that technological innovation is a precursor to innovation in the business model (Souto, 2015), while others argue that innovation in the business model is the determinant of technological innovation (Wei et al., 2014). Hence, this study aims to investigate the relationship between technological innovation and business model innovation, and to examine their interplay against company's success performance.

This research paper is structured as follows. First, the theoretical framework of the paper is presented. Second, the concepts of business model innovation and technological innovation are clearly presented, and research hypotheses are elaborated. What follows are the research design and methodology. Finally, the data analysis and discussion of the results are presented, as well as the contributions and limitations of our study.

\section{LITERATURE REVIEW}

\subsection{Theoretical Foundation}

Theoretical foundation for this study is the Resource-Based Theory (RBT) or Resource-Based View (RBV). RBV is one of the most important theoretical frameworks for understanding how a company achieves superior performance and maintains a competitive edge (Barney, 1991; Penrose, 1995; Wernerfelt, 1984). The basic premise of RBV is that successful performance depends on the resources (capabilities, competencies) the company possesses (Martinez-Conesa, Soto-Acosta, \& Carayannis, 2017). Performance differences between companies result from a different portfolio of resources (Fredericks, 2005). Barney (1991) considers resources as all assets, capabilities, organizational processes, characteristics, information, knowledge, and other elements controlled by the company, which the company applies in the process of creating and implementing strategies that should ultimately result in organizational efficiency and effectiveness. In order to have the potential to gain and sustain a competitive advantage, resources need to possess the following four characteristics: valuable, rare, imperfectly imitable, and with no strategically equivalent substitute (Barney, 1991). The literature identifies different types of innovation as one of the most important sources of success performances (Camisón \& Villar-López, 2014; Clauss, Abebe, Tangpong, \& Hock, 2019). Therefore, in order to explain the logic behind the relationship between technological innovation and business model innovation, as well as their connections with organizational business performances, we use RBV.

\subsection{Technological Innovation}

In modern society, "innovation plays a central role in the business of companies" (Teece, 2010b, p. 724). Damanpour \& Evan (1984) view innovation as a response to environmental changes, or a means, by which changes in an organization are affected. Innovation involves having specific technical knowledge that points to new ways of doing business (Teece, 1986). Garcia \& Calantone (2002) distinguish innovation by 
the degree of "radicality" into incremental (exploitative) and radical (explorative) innovation. In addition to these, it is common to classify innovations into technological and non-technological innovations (Mothe \& Uyen Nguyen Thi, 2010).

Technological innovation involves generating and adopting new ideas in the operating process, production system, products, and services (Damanpour \& Evan, 1984). In other words, technological innovation may be related to the introduction of new technical knowledge of how to conduct business in a different or better way, for example, in a firm's production system, its operating processes, or its products and services (Teece, 1986). Heij (2015, p. 4) states that technological innovation refers to the introduction of (a) new technical knowledge, or (b) technological innovation of products/services and processes that embody new technological knowledge. Schmidt \& Rammer (2007) link product and process innovation to the development and implementation of new technologies, and classify them as technological innovations (OECD, 2005).

\subsection{Business model and business model innovation}

The concept of business model has become a dominant field of interest in the management literature (Dmitriev et al., 2014; Maucuer \& Renaud, 2019). The widespread use of the business model construct was evident in the early 1990s, with the advent of the Internet and the development of IT, which enables companies to fundamentally change the way they do their business and indicates that business model innovation is a vast area of research.

In general, Hamel (2002) describes the business model as a "way of doing business", while Magretta (2002) states that the business model explains how the company operates and is fundamentally an insight into value creation. In the process, the potential for value creation stems from the design of transactions between companies and external stakeholders (Amit $\&$ Zott, 2001). Innovation of the business model involves the introduction of entirely new business logic or at least an improvement in existing business logic, creating value for the company (CasadesusMasanell \& Zhu, 2013; Markides, 2006). By identifying the business model, Amit \& Zott (2001) describe it as "the content, structure, and governance of transactions designed to create value through the exploitation of business opportunities " ( $\mathrm{p}$. 511). The content of the business model implies the goods and information that are exchanged and the capabilities and resources needed to enable the exchange. In fact, business model content is about choosing which activities to perform (Zott $\&$ Amit, 2010). The structure of transactions relates to the exchange between participants and the way in which they are connected. The selection of a transaction structure significantly affects the flexibility and adaptability of existing transactions (Amit \& Zott, 2001). Transaction governance involves a way of controlling the flow of resources, information, and goods by the participants. Companies may decide to reduce production and transaction costs by innovating the business model, or by engaging in new ways of achieving economic exchange between different parties (Zott \& Amit, 2007). According to the literature, there are two basic ways to implement this: the first one relates to the efficiency-centered business model innovation and the second one to the novelty-centered business model innovation (Guo, Pang, \& $\mathrm{Li}, 2017)$. They both represent the dimensions of business model innovation (Zott \& Amit, 2007). 


\subsection{Hypotheses development}

\subsubsection{Technological innovation and business model innovation}

One of the critical issues in studying business models and technological innovations is their interconnectedness (Amit \& Zott, 2001; Teece, 2010a; Tongur \& Engwall, 2014). Despite the significant potential for advancement in research on this relationship in both science and practice (Baden-Fuller \& Haefliger, 2013) to date, little attention has been devoted to the relationship between these two concepts. Innovative activities are generally considered an asset for organizations, as they are necessary for the development of new products and procedures and new business models, and crucial to maintaining market advantage (Huang et al., 2012). The findings of previous studies emphasized that technological innovation fits with company's strategy (Teece, 1986) in creating and delivering value, and represents the key element in improving company's performance in a turbulent environment (Jansen, Van Den Bosch, \& Volberda, 2006). However, the opinion prevailing in the literature is that business models remain unchanged so very little attention has been paid to business models (Teece, 2010a). Chesbrough \& Rosenbloom (2002a) claim that the "business model reveals hidden value from technology" (p. 529). This reasoning implies that commercialization of a new technology can be achieved in many ways through different business models (Chesbrough, 2007).

Pucihar et al. (2019) claim that innovation positively influences the level of business model innovation, while Bouwman, Nikou, Molina-Castillo, \& de Reuver (2018) confirm that innovation activities are positively related to the business model experimentation processes. Calia, Guerrini, \& Moura (2007) show that technological innovation can drive change in operational and commercial activities of a company, and its business model. Business model innovations are a type of innovation, distinct from the process or product innovation (OECD, 2012). As products or services offered and business processes used affect the business model value proposition, service or product innovation and process innovation can drive business model innovation (Bucherer, Eisert, \& Gassmann, 2012). Based on the discussion, the following research hypothesis can be defined:

\section{H1: Technological innovation influences} business model innovation.

\subsubsection{Business model innovation and company performance}

In growing and changing business environment, innovation of business model is seen as a critical source of competitive advantage (Amit \& Zott, 2012; CasadesusMasanell \& Zhu, 2013) and one of the most important determinants of modern companies in achieving success (Chesbrough \& Rosenbloom, 2002b; Giesen, Riddleberger, Christner, \& Bell, 2010; Zott, Amit, \& Massa, 2011). Business model innovation primarily focuses on finding new ways of generating revenue and defining value propositions for partners, suppliers, and customers (Teece, 2010a).

Several studies have confirmed the positive impact of business model innovation on company's performance (Aspara, Hietanen, \& Tikkanen, 2010; Futterer, Schmidt, \& Heidenreich, 2018; Visnjic, Wiengarten, \& Neely, 2016). Futterer et al. (2018) claim that business model innovation enhances corporate venture performance, while Huang, Lai, Lin, \& Chen (2013) believe that business model innovations help companies to build competitive advantage, by creating a new business 
model, that generates value for customers. These authors further conclude that only by continuously innovating products, services, and the business models, a company can survive, and, thus, improve the business and produce higher value. Pohle \& Chapman (2006) find that companies, if enhancing business model innovation, can achieve optimal benefits resulting in cost reductions and strategic flexibility. The results of the study conducted by Visnjic et al. (2016) emphasize that the joint implementation of "service" business model innovation and product innovation has a positive effect on long-term performance, while the implementation of service business model innovation alone has a positive effect on short-term performance. Similar conclusions were reached by Zott \& Amit (2008) in investigating the influence of novelty-centered business model design and production market strategies on company's business performance, proving their positive influence. By identifying three types of business model innovations - industry model, revenue model, and company model, Giesen, Berman, Bell, \& Blitz (2007) find that all three types contribute to business success performance. By examining the factors that influence organizational business performance on a sample of 376 small and medium-sized Italian companies, Cucculelli \& Bettinelli (2015) confirmed that changes in the business model enable companies to reach better results. Besides, a positive influence on performance was also confirmed in the interplay of changes in business models and intangible assets. The results confirmed that this influence is more significant if the degree of business model innovation is greater and that business model innovation is the basis for company's success. Therefore, Cucculelli \& Bettinelli (2015) concluded that business model innovation performs a crucial role in achieving better performance. In this regard, we propose the following hypothesis:

H2: Business model innovation has a positive influence on company's performance.

\subsubsection{Technological innovation, business model innovation, and company performance}

Few studies in the literature have addressed business model innovation, technological innovation, and their interplay towards company's business performance, especially with empirical evidence. However, some conceptual studies suggest that business models are substantially related to technological innovation, although the construction of the business model is fundamentally separate from technology (e.g., Baden-Fuller \& Haefliger, 2013). Furthermore, Baden-Fuller \& Haefliger (2013) propose that business model innovation acts as a mediator in the relationship between technological innovation and company performance. The rationale of this relationship is that technological advances fail commercially, unless business model design adapts to the new technology or product (Wei, Yang, Sun, \& Gu, 2014). In other words, technological innovation can be a significant driver of company's growth if there is an appropriate business model design. In this regard, we propose the following hypothesis:

H3: Business model innovation mediates the relationships between technological innovation and company's performance.

\section{METHODOLOGY}

\subsection{Sample}

A survey technique has been used for data collection in the present study. Content and nomological validity is ensured by adjusting 
and applying validated measurement instruments, and by taking into account the opinions of panels of experts from the academic and business community (Kianto, Sáenz, \& Aramburu, 2017). The questionnaire was grouped into following categories: business model innovation, technological innovation, performance, and demographic characteristics of the company and the respondents.

Using the database of the largest credit rating company in Bosnia and Herzegovina, which includes all registered active medium- and large-sized companies, a questionnaire was distributed. The questionnaire with the cover letter was e-mailed to the managers of companies using the LimeSurvey software. Out of 1,137 calls sent, 320 questionnaires were collected, implying that the response rate was $28.14 \%$. After preliminary data examination (Hair, Black, \& Babin, 2010), a total of 264 valid questionnaires were used in the analysis and hypotheses testing. The sample consisted of $17.05 \%$ large and $82.95 \%$ medium companies. Data were inspected for non-response bias, comparing characteristics of early and late research participants (Martinez-Conesa et al., 2017). The results of the Chi-Square test showed that non-response bias does not compromise the results and their interpretation (Chi-Square $=0.015, \mathrm{p}=0.903)$. We used confirmatory factor analysis (CFA) for the comparison between the proposed conceptual model and the constrained single-factor model (Johnson, Martin, \& Saini, 2012). A single latent factor would account for all manifest variables if there were common method variance. In addition, the overall model fit $(\chi 2$ $=2,582.722(\mathrm{p}=0.000) ; \mathrm{df}=209$; RMSEA $=0.208 ; \mathrm{SRMR}=0.139 ; \mathrm{CFI}=0.788 ; \mathrm{NFI}$ $=0.769$ ) revealed by the single factor model indicates the absence of common method bias.

\subsection{Measures}

The scales of the three variables were adopted from the existing literature. Using a seven-point Likert scale ranging from (1) "strongly disagree" to (7) "strongly agree" items were measured.

Table 1. Measuring variables and items

\begin{tabular}{|c|c|c|c|c|}
\hline Construct & Code & Item & St loadings & $t$-value \\
\hline \multirow{6}{*}{$\begin{array}{l}\text { Technological } \\
\text { innovation (TI) }\end{array}$} & TI1 & $\begin{array}{l}\text { "Our unit accepts demands that go } \\
\text { beyond existing products and services." }\end{array}$ & 0.663 & - \\
\hline & TI2 & $\begin{array}{l}\text { "We commercialize products and } \\
\text { services that are completely new to our } \\
\text { company." }\end{array}$ & 0.749 & 10.551 \\
\hline & $\mathrm{TI} 3$ & $\begin{array}{l}\text { "We frequently utilize new opportunities } \\
\text { in new markets." }\end{array}$ & 0.833 & 11.473 \\
\hline & TI4 & $\begin{array}{l}\text { "Our company regularly uses new } \\
\text { distribution channels." }\end{array}$ & 0.834 & 11.489 \\
\hline & TI5 & $\begin{array}{l}\text { "We introduce improved, but existing } \\
\text { products and services for our local } \\
\text { market." }\end{array}$ & 0.625 & 9.029 \\
\hline & TI6 & $\begin{array}{l}\text { "Our company expands services for } \\
\text { existing clients." }\end{array}$ & 0.770 & 10.789 \\
\hline
\end{tabular}




\begin{tabular}{|c|c|c|c|c|}
\hline \multirow{6}{*}{$\begin{array}{l}\text { Efficiency- } \\
\text { centred business } \\
\text { model innovation } \\
\text { (BMDE) }\end{array}$} & BMDE1 & $\begin{array}{l}\text { "The business model enables a low } \\
\text { number of errors in the execution of } \\
\text { transactions." }\end{array}$ & 0.700 & - \\
\hline & BMDE2 & $\begin{array}{l}\text { "Costs other than those already } \\
\text { mentioned for participants in the business } \\
\text { model are reduced (i.e., marketing and } \\
\text { sales costs, transaction-processing costs, } \\
\text { communication costs, etc.)." }\end{array}$ & 0.618 & 9.397 \\
\hline & BMDE3 & $\begin{array}{l}\text { "The business model is scalable (i.e., can } \\
\text { handle small as well as a large number of } \\
\text { transactions)." }\end{array}$ & 0.882 & 13.055 \\
\hline & BMDE4 & $\begin{array}{l}\text { "The business model enables participants } \\
\text { to make informed decisions." }\end{array}$ & 0.747 & 11.261 \\
\hline & BMDE5 & $\begin{array}{l}\text { "As part of transactions, information is } \\
\text { provided to participants to reduce the } \\
\text { asymmetric degree of knowledge amongst } \\
\text { them regarding the quality and nature of } \\
\text { the goods being exchanged." }\end{array}$ & 0.775 & 11.656 \\
\hline & BMDE6 & $\begin{array}{l}\text { "The business model enables fast } \\
\text { transactions." }\end{array}$ & 0.776 & 11.679 \\
\hline \multirow{6}{*}{$\begin{array}{l}\text { Novelty-centered } \\
\text { business model } \\
\text { innovation (BMDI) }\end{array}$} & BMDI1 & $\begin{array}{l}\text { "Incentives offered to participants in } \\
\text { transactions are novel." }\end{array}$ & 0.779 & - \\
\hline & BMDI2 & $\begin{array}{l}\text { "The business model gives across to an } \\
\text { unprecedented variety and number of } \\
\text { participants and/or goods." }\end{array}$ & 0.885 & 16.048 \\
\hline & BMDI3 & $\begin{array}{l}\text { "The business model links participants to } \\
\text { transactions in novel ways." }\end{array}$ & 0.911 & 16.644 \\
\hline & BMDI4 & $\begin{array}{l}\text { "The richness (i.e., quality and depth) of } \\
\text { some of the links between participants is } \\
\text { novel." }\end{array}$ & 0.856 & 15.397 \\
\hline & BMDI5 & $\begin{array}{l}\text { "It has increased the extent to which the } \\
\text { business model relies on trade secrets } \\
\text { and/or copyrights." }\end{array}$ & 0.565 & 9.369 \\
\hline & BMDI6 & $\begin{array}{l}\text { "The focal firm has continuously } \\
\text { introduced innovations in its business } \\
\text { model." }\end{array}$ & 0.641 & 10.814 \\
\hline \multirow{4}{*}{$\begin{array}{l}\text { Success } \\
\text { performances (SP) }\end{array}$} & SP1 & $\begin{array}{l}\text { "We have enhanced the sales and } \\
\text { profitability of the firm." }\end{array}$ & 0.595 & - \\
\hline & SP2 & "We have achieved profit objectives." & 0.900 & 10.971 \\
\hline & SP3 & "We have achieved sales objectives." & 0.962 & 11.257 \\
\hline & SP4 & $\begin{array}{l}\text { "We have achieved market share } \\
\text { objectives." }\end{array}$ & 0.818 & 10.352 \\
\hline Company's size & \multicolumn{4}{|c|}{ Size Number of employees } \\
\hline Company's age & \multicolumn{4}{|c|}{ Age Number of years since the firm was founded } \\
\hline Source: & \multicolumn{4}{|c|}{$\begin{array}{l}\text { Author (items adopted from Jansen at al., 2006; Zott \& Amit, 2007; Chen et } \\
\text { al., 2009) }\end{array}$} \\
\hline
\end{tabular}


Table 1. lists the items of key variables used in this study, along with their validity estimates.Technological innovation (TI) measurement model was developed using indicators proposed by Jansen et al. (2006). It is a first-order reflective construct consisting of six items.

Business model innovation (BMD) is a second-order reflective construct that consisted of two first-order factors: efficiency-centered business model innovation (BMDE) and novelty-centered business model innovation (BMDI) with 12 manifest variables adopted from Zott \& Amit (2007).

Success performance (SP) This firstorder measurement scale was adapted from Chen, Hung, \& Huang (2009), and it consisted of four items measuring company's success performance (SP) related to sales and profitability, planed sales, profit, and market share.

As in previous studies dealing with innovation and their influence on success performances (Chen et al., 2009; Turulja \& Bajgorić, 2018; Zott \& Amit, 2007), two control variables were included: company's size and age.

\subsection{Methodology}

Confirmatory factor analysis (CFA) and Structural equation modeling (SEM) were utilized for the examination, using Lisrel 8.8. SEM can simultaneously analyze a set of multiple cause and effect relationships and is, therefore, considered as the best multivariate technique for testing the structural model consisting of measurement models (Hair et al., 2014).

\section{RESULTS AND DISCUSSION}

We adopted a two-step approach to SEM recommended by Anderson \& Gerbing,
(1988). First, the evaluation of the measurement models to test their reliability and validity using CFA was conducted individually for three scales. Then, the assessment of the structural model was conducted by using SEM (Anderson \& Gerbing, 1988).

\subsection{Reliability and validity tests}

First, scales were tested using CFA aiming to verify dimensionality, reliability, convergent and discriminant validity (Hair, Black, Babin, \& Anderson, 2014). Overall model fit was evaluated by using the Goodness of Fit (GoF) indices (Chi-square, RMSEA, SRMR, CFI, NFI) as suggested by Hair et al. (2014). The reliability of the measures was initially assessed by examining inter-item and item-to-total correlation (Calantone, Cavusgil, \& Zhao, 2002), as well as checking Composite Reliability (CR) and Average Variance Extracted (AVE) indicators (Hair et al., 2014). The reliability of measures is supported by $\mathrm{CR}>0.7$ and AVE $>0.5$ (see Table 2). Convergent validity is achieved by obtaining factor loadings for each item with the value higher than 0.5 (see Table 1) (PérezAróstegui, Bustinza-Sánchez, \& BarralesMolina, 2014). Finally, we assessed the discriminant validity of the constructs following Fornell \& Larcker (1981) suggestion by assessing the square root of the AVE to be greater than all corresponding correlations. Then, CFA with all constructs was performed revealing good model fit: $\chi^{2}=$ $410.981(\mathrm{p}=0.000) ; \mathrm{df}=203 ;$ RMSEA $=$ 0.0624; $\mathrm{SRMR}=0.0593$; $\mathrm{CFI}=0.973$; NFI $=0.950$ ), and correlations are presented in Table 2.

Based on the conducted analyses, it was confirmed that all measures meet the assumed criteria of reliability and validity, and, as such, may be subject to further analysis and hypotheses testing. 
Journal of Contemporary Management Issues

Table 2. Results of Reliability and Validity Tests for Measures

\begin{tabular}{|l|c|c|c|c|c|c|}
\hline Dimensions & CR & AVE & BMDE & BMDI & TI & SP \\
\hline $\begin{array}{l}\text { Efficiency-centered BMD } \\
\text { (BMDE) }\end{array}$ & 0.887 & 0.568 & $\mathbf{0 . 7 5 4}$ & & & \\
\hline Novelty-centered BMD (BMDI) & 0.903 & 0.614 & 0.616 & $\mathbf{0 . 7 8 3}$ & & \\
\hline Technological innovation (TI) & 0.884 & 0.562 & 0.529 & 0.553 & $\mathbf{0 . 7 5 0}$ & \\
\hline $\begin{array}{l}\text { Company's success } \\
\text { performances (SP) }\end{array}$ & 0.896 & 0.690 & 0.137 & 0.170 & 0.188 & $\mathbf{0 . 8 3 0}$ \\
\hline $\begin{array}{l}\text { Notes: CR }=\text { Composite } \\
\text { reliability; } \text { AVE = Average } \\
\text { Variance Extracted; } \text { Squared- } \\
\text { root AVEs are shown on the } \\
\text { diagonal in bold; } \text { Construct } \\
\text { correlations are shown below the } \\
\text { diagonal. }\end{array}$ & & & & & & \\
\hline
\end{tabular}

\subsection{Hypotheses testing}

SEM was utilized to analyse the hypothesized relationships, as well as the overall fit (Hair et al., 2014) of the model constructed according to the resource-based view. First, the overall model is checked by using GoF indices and the results confirm that the data fit the model well: $(\chi 2=$ $438.798(\mathrm{p}=0.000) ; \mathrm{df}=245 ; \mathrm{RMSEA}=$ 0.0548 ; $\mathrm{SRMR}=0.0572$; $\mathrm{CFI}=0.975$; NFI $=0.947$ ). In the following analysis, path estimation with SEM was used for hypotheses testing.

Table 3. Path Analysis

\begin{tabular}{|c|c|c|c|}
\hline Hypotheses & Paths & $\begin{array}{l}\text { Stand. } \\
\text { Coeff. }\end{array}$ & $t$ - value \\
\hline H1: & Technological innovation $\rightarrow$ BMD & $0.695 * * *$ & 6.776 \\
\hline $\mathrm{H} 2$ : & BMD $\rightarrow$ Success Performance & $0.223 * * *$ & 2.915 \\
\hline H3: & $\begin{array}{l}\text { Technological innovation } \rightarrow \text { BMD } \rightarrow \text { Success } \\
\text { Performance }\end{array}$ & $0.155 * * *$ & 2.893 \\
\hline Control: & Age $\rightarrow$ Success Performance & $0.070 * * *$ & 1.081 \\
\hline Control: & Size $\rightarrow$ Success Performance & $0.058^{* * *}$ & 0.912 \\
\hline \multicolumn{4}{|c|}{$\begin{array}{l}\chi 2=438.798(\mathrm{p}=0.000) ; \mathrm{df}=245 ; ; \mathrm{RMSEA}=0.0548 ; \mathrm{SRMR}=0.0572 ; \mathrm{CFI}=0.975 ; \mathrm{NFI}= \\
0.947\end{array}$} \\
\hline \multicolumn{4}{|c|}{$* * * \mathrm{p}<0.01 ; * * \mathrm{p}<0.05 ; * \mathrm{p}<0.1$} \\
\hline
\end{tabular}

Our research supported hypotheses $\mathrm{H} 1$ through H3. The results indicated a significant positive influence of technological innovation $(\beta=0.695, p<0.01)$ on business model innovation. A significant positive impact of business model innovation $(\beta=$
$0.223, \mathrm{p}<0.01$ ) on organizational performance was also found. Finally, the results supported the mediated role of business model innovation in the relationship between technological innovation and business success $(\beta=0.155, p<0.01)$. A 
significant indirect effect indicates that a significant amount of the total impact of the independent variables on the dependent variable occurs through the mediator (Rhee et al., 2010). In addition, we assessed the significance of the mediation effect using the Sobel test. The Sobel test is "an approximate significance test for the indirect effect of the independent variable on the dependent variable via the mediator" (Baron \& Kenny, 1986). The mediation test (Sobel test statistic $=2.677, \mathrm{p}<0.01$ ) confirmed that BMD significantly mediated the effect of technological innovation on company's success performances. Furthermore, company size (Baden-Fuller \& Haefliger, 2013) and age (Tsai, Liao, \& Hsu, 2015) were included as control variables in the model as they were able to explain variations in organizational performance, and may help to test the model robustness (Lim, Stratopoulos, \& Wirjanto, 2011). However, our results confirmed the robustness of the model regardless of company's size or age, i.e. control variables did not have a statistically significant impact on the company's successful performance.

\section{CONCLUSION}

The present study explored the role of technological innovation and business model innovation in organizational business success. The sample consisted of 264 medium and large companies from an emerging country in South-Eastern Europe (SEE). As discussed, technological innovation and business model innovation are key factors for a company's success in the turbulent contemporary business environment. Despite its significance, only a limited set of research considered this when clarifying the relationships between innovation and company's business success. Therefore, our study attempted to explain the impact of technological innovation as one of the most significant types of innovation on business model innovation, and indirectly on business success.

Our results empirically confirmed that technological innovation enhances business model innovation, and ultimately organizational business performance. In this regard, business model innovation plays a central role in business success, while IT is a driver that promotes other types of innovation. Our results adhere to the foundation theory and RBV, according to which superior business performance relies on organizational resources and capabilities (Bharadwaj, 2000). Our results are in agreement with the recommendations of Wei et al. (2014), who argued that technological advances usually fail commercially because scant attention is paid to designing or innovating a business model. In other words, while technological innovation can be a major driver of growth for companies, its actual impact may depend on whether there is, indeed, a suitable business model design (Wei et al., 2014). In this regard, business model innovation is the mediator between technological innovation and business success. Hence, both business model innovation and technological innovation contribute to company's business success.

This research adds to the existing management and innovation literature by empirically investigating the relation between technological innovation, business model innovation, and company's performance. This is of particular importance, given the disagreement in the literature, regarding the relationship between technological innovation and business model innovation. While some studies suggest that technological innovation is an antecedent to business model innovation (Souto, 2015), others claim that business model innovation is a determinant of 
technological innovation (Wei et al., 2014). Our results indicate that, in our research context, technological innovation enhances business model innovation and, ultimately, the company's business success. Technological innovation cannot succeed in the market without an adequate business model (BadenFuller \& Haefliger, 2013).

Finally, here are limitations of our study. First, the research was conducted with the data from one country only. Therefore, in order for the results to be generalizable, the model needs to be validated, in at least one more research context. In addition, future research should confirm our results in light of specific industrial sectors.

\section{REFERENCES}

1. Amit, R., \& Zott, C. (2001). Value Creation in E-Business. Strategic Management Journal, 22(6/7), 493-520. doi:10.2307/3094318

2. Amit, R., \& Zott, C. (2012). Creating Value Through Business Model Innovation. MIT Sloan Management Review, 53(3), 41-49.

3. Anderson, J. C., \& Gerbing, D. W. (1988). Structural equation modeling in practice: A review and recommended two-step approach. Psychological bulletin, 103(3), 411.

4. Anning-Dorson, T. (2017). How much and when to innovate The nexus of environmental pressures, innovation and service firm performance. European Journal of Innovation Management, 20(4), 599-619. https://doi. org/10.1108/EJIM-05-2016-0050

5. Aspara, J., Hietanen, J., \& Tikkanen, H. (2010). Business model innovation vs replication: financial performance implications of strategic emphases. Journal of
Strategic Marketing, 18(1), 39-56. doi:10.1080/09652540903511290.

6. Baden-Fuller, C., \& Haefliger, S. (2013). Business Models and Technological Innovation. Long Range Planning, 46(6), 419-426. doi:10.1016/j. lrp.2013.08.023

7. Baković, T., \& Ledić-Purić, D. (2011). Uloga inovacija u poslovanju malih i srednjih poduzeća. Poslovna izvrsnost, Zagreb, V(1).

8. Barney, B. J. (1991). Firm Resources and Sustained Competitive Advantage. Journal of Management, 17(1), 99.

9. Baron, R. M., \& Kenny, D. A. (1986). The moderator-mediator variable distinction in social psychological research: Conceptual, strategic, and statistical considerations. Journal of Personality and Social Psychology, 51(6), 1173-1182.

10. Bashir, M. (2019). Internal factors $\&$ consequences of business model innovation. Management Decision, 57(1), 262-290. doi:10.1108/ MD-11-2016-0784

11. Bharadwaj, A. S. (2000). A resourcebased perspective on information technology capability and firm performance: an empirical investigation. MIS quarterly, 24(1), 169-196.

12. Bouwman, H., Nikou, S., Molina-Castillo, F. J., \& de Reuver, M. (2018). The impact of digitalization on business models. Digital Policy, Regulation and Governance, 20(2), 105-124. doi:doi:10.1108/DPRG-07-2017-0039

13. Bucherer, E., Eisert, U., \& Gassmann, O. (2012). Towards Systematic Business Model Innovation: Lessons from Product Innovation Management. Creativity \& Innovation Management, 21(2), 183-198. doi:10.1111/j.1467-8691.2012.00637.x 
14. Calantone, R. J., Cavusgil, S. T., \& Zhao, Y. (2002). Learning orientation, firm innovation capability, and firm performance. Industrial Marketing Management, 31(6), 515-524.

15. Calia, R. C., Guerrini, F. M., \& Moura, G. L. (2007). Innovation networks: From technological development to business model reconfiguration. Technovation, 27(8), 426432. doi:http://dx.doi.org/10.1016/j. technovation.2006.08.003

16. Camisón, C., \& Villar-López, A. (2014). Organizational innovation as an enabler of technological innovation capabilities and firm performance. Journal of Business Research, 67(1), 28912902. doi:https://doi.org/10.1016/j. jbusres.2012.06.004

17. Casadesus-Masanell, R., \& Zhu, F. (2013). Business model innovation and competitive imitation: The case of sponsor-based business models. Strategic Management Journal, 34(4), 464482. doi:10.1002/smj.2022

18. Chen, J.-S., Hung, T. T., \& Huang, A. Y.-H. (2009). Service Delivery Innovation:Antecedents and Impact on Firm Performance. Journal of Service Research, 12(1), 36-55. doi:10.1177/1094670509338619

19. Chesbrough, H. (2007). Business model innovation: it is not about technology anymore. Strategy \& Leadership, 35(6), 12-17. doi:DOI 10.1108/10878570710833714

20. Chesbrough, H. (2010). Business Model Innovation: Opportunities and Barriers. Long Range Planning, 43(2-3), 354-363. doi:10.1016/j.lrp.2009.07.010

21. Chesbrough, H., \& Rosenbloom, R. S. (2002a). The role of the business model in capturing value from innovation: evidence from Xerox Corporation's technology spin-off companies. Industrial and Corporate Change, 11(3), 529-555. doi:10.1093/icc/11.3.529

22. Chesbrough, H., \& Rosenbloom, R. S. (2002b). The role of the business model in capturing value from innovation: evidence from Xerox Corporation's technology spin-off companies. Industrial and Corporate Change, 11(3), 529-555.

23. Clauss, T., Abebe, M., Tangpong, C., \& Hock, M. (2019). Strategic Agility, Business Model Innovation, and Firm Performance: An Empirical Investigation. IEEE Transactions on Engineering Management, 1-18. doi:10.1109/ TEM.2019.2910381

24. Cucculelli, M., \& Bettinelli, C. (2015). Business models, intangibles and firm performance: evidence on corporate entrepreneurship from Italian manufacturing SMEs. Small Business Economics, 45(2), 329-350. doi:10.1007/ s11187-015-9631-7

25. Damanpour, F., \& Evan, M. W. (1984). Organizational Innovation and Performance: The problem of organisational Lag. Administrative Science Quarterly, 29(3), 392-409.

26. Desyllas, P., \& Sako, M. (2013). Profiting from business model innovation: Evidence from Pay-As-You-Drive auto insurance. Research Policy, 42(1), 101116. doi:http://dx.doi.org/10.1016/j. respol.2012.05.008

27. Dmitriev, V., Simmons, G., Truong, Y., Palmer, M., \& Schneckenberg, D. (2014). An exploration of business model development in the commercialization of technology innovations. $R \& D$ Management, 44(3), 306-321. doi:10.1111/radm.12066

28. Fornell, C., \& Larcker, D. F. (1981). Structural Equation Models with 
Unobservable Variables and Measurement Error: Algebra and Statistics. Journal of Marketing Research, 18(3), 382-388. doi: $10.2307 / 3150980$

29. Fredericks, E. (2005). Infusing flexibility into business-to-business firms: A contingency theory and resource-based view perspective and practical implications. Industrial Marketing Management, 34(6), 555-565. doi:https://doi. org/10.1016/j.indmarman.2004.09.022

30. Futterer, F., Schmidt, J., \& Heidenreich, S. (2018). Effectuation or causation as the key to corporate venture success? Investigating effects of entrepreneurial behaviors on business model innovation and venture performance. Long Range Planning, 51(1), 64-81. doi:https://doi.org/10.1016/j. lrp.2017.06.008

31. Garcia, R., \& Calantone, R. (2002). A critical look at technological innovation typology and innovativeness terminology: a literature review. Journal of Product Innovation Management, 19(2), 110-132. doi:10.1111/1540-5885.1920110

32. Giesen, E., Berman, S. J., Bell, R., \& Blitz, A. (2007). Three ways to successfully innovate your business model. Strategy \& Leadership, 35(6), 2733. doi:10.1108/10878570710833732

33. Giesen, E., Riddleberger, E., Christner, R., \& Bell, R. (2010). When and how to innovate your business model. Strategy \& Leadership, 38(4), 17-26. doi:d oi:10.1108/10878571011059700

34. Guo, B., Pang, X., \& Li, W. (2017). The role of top management team diversity in shaping the performance of business model innovation: a threshold effect. Technology Analysis \& Strategic Management, 1-13. doi:10.1080/09537 325.2017.1300250
35. Hair, F. J., Black, W. C., \& Babin, B. J. (2010). Multivariate Data Analysis: A Global Perspective: Pearson Education.

36. Hair, J. F., Black, W. C., Babin, B. J., \& Anderson, R. E. (2014). Multivariate Data Analysis. Prentice-Hall, Inc (Seventh ed). Pearson Education Limited 2014. https://doi.org/10.1038/259433b0

37. Hamel, G. (2002). Leading the Revolution: How to Thrive in Turbulent Times by Making Innovation a Way of Life: Harvard Business School Press.

38. Heij, C. V. (2015). Innovating beyond Technology - Studies on how management innovation, co-creation and business model innovation contribute to firms' (innovation) performance. (PhD), Erasmus University Rotterdam.

39. Heij, C. V., Volberda, H. W., \& Van Den Bosch, F. A. J. (2014). How does Business Model Innovation Influence Firm Performance: The Moderating Effect of Environmental Dynamism $\mathrm{Pa}$ per presented at the Academy of Management Annual Meeting Proceedings.

40. Hossain, M. (2017). Business model innovation: past research, current debates, and future directions. Journal of Strategy and Management, 10(3), 342-359.

41. Huang, H. C., Lai, M. C., Kao, M. C., \& Chen, Y. C. (2012). Target Costing, Business Model Innovation, and Firm Performance: An Empirical Analysis of Chinese Firms. Canadian Journal of Administrative Sciences / Revue Canadienne des Sciences de l'Administration, 29(4), 322-335. doi:10.1002/cjas.1229

42. Huang, H. C., Lai, M. C., Lin, L. H., \& Chen, C. T. (2013). Overcoming organizational inertia to strengthen business model innovation An open innovation perspective. Journal of Organizational 
Change Management, 26(6), 977-1002. doi:10.1108/jocm-04-2012-0047

43. Hult, G. T. M., Hurley, R. F., \& Knight, G. A. (2004). Innovativeness: Its antecedents and impact on business performance. Industrial Marketing Management, 33(5), 429-438. doi:https://doi. org/10.1016/j.indmarman.2003.08.015

44. Jansen, J. J. P., Van Den Bosch, F. A. J., \& Volberda, H. W. (2006). Exploratory Innovation, Exploitative Innovation, and Performance: Effects of Organizational Antecedents and Environmental Moderators. Management Science, 52(11), 1661-1674.

45. Johnson, M. W., Christensen, C. M., \& Kagermann, H. (2008). Reinventing Your Business Model. Harvard Business Review, 86(12), 50-59.

46. Johnson, J. L., Martin, K. D., \& Saini, A. (2012). The role of a firm's strategic orientation dimensions in determining market orientation. Industrial Marketing Management, 41(4), 715-724. https://doi.org/10.1016/j. indmarman.2011.09.01.

47. Kianto, A., Sáenz, J., \& Aramburu, N. (2017). Knowledge-based human resource management practices, intellectual. Journal of Business Research, 81, 11-20. https://doi.org/10.1016/j. jbusres.2017.07.018.

48. Lim, J. H., Stratopoulos, T., \& Wirjanto, T. (2011). Path dependence of dynamic information technology capability: An empirical investigation. Journal of Management Information Systems, 28(3), 45-84. https://doi.org/10.2753/ MIS0742-1222280302

49. Magretta, J. (2002). Why Business Models Matter. Harvard Business Review, 80(5), 86-92.

50. Markides, C. (2006). Disruptive Innovation: In Need of Better Theory. Journal of Product Innovation Management, 23(1), 19-25. doi:10.1111/j.1540-5885.2005.00177.x.

51. Martinez-Conesa, I., Soto-Acosta, P., \& Carayannis, E. G. (2017). On the path towards open innovation: assessing the role of knowledge management capability and environmental dynamism in SMEs. Journal of Knowledge Management, 21(3), 553-570. https://doi. org/10.1108/JKM-09-2016-0403.

52. Maucuer, R., \& Renaud, A. (2019). Business Model Research: A Bibliometric Analysis of Origins and Trends. M@n@gement, 22(2), 176-215.

53. Mothe, C., \& Uyen Nguyen Thi, T. (2010). The link between nontechnological innovations and technological innovation. European Journal of Innovation Management, 13(3), 313-332. https://doi. org/10.1108/14601061011060148.

54. OECD. (2005). Oslo Manual: Guidelines for Collecting and Interpreting Innovation Data (3. Edition ed.). Paris: OECD Publications.

55. OECD. (2012). The Future of Eco-Innovation: The Role of Business Models in Green Transformation. Paris.

56. Osterwalder, A. (2004). The Business Model Ontology: a Proposition in a Design Science Approach. (Doctoral thesis), University of Lausanne, Switzerland.

57. Penrose, E. T. (1995). The theory of the growth of the firm (3rd. ed.). New York: Oxford University Press.

58. Pérez-Aróstegui, M. N., BustinzaSánchez, F., \& Barrales-Molina, V. (2014). Exploring the relationship between information technology competence and quality management. Business Research Quarterly, 18(1), 4-17. https://doi.org/10.1016/j. brq.2013.11.003

59. Pohle, G., \& Chapman, M. (2006). IBM's global CEO report 2006: 
business model innovation matters. Strategy \& Leadership, 34(5), 34-40. doi:10.1108/10878570610701531

60. Pucihar, A., Lenart, G., Kljajić Borštnar, M., Vidmar, D., \& Marolt, M. (2019). Drivers and Outcomes of Business Model Innovation-Micro, Small and Medium-Sized Enterprises Perspective. Sustainability, 11(2), 344.

61. Rhee, J., Park, T., \& Hyung, D. (2010). Technovation Drivers of innovativeness and performance for innovative SMEs in South Korea: Mediation of learning orientation. Technovation, 30(1), 65-75. https://doi.org/10.1016/j. technovation.2009.04.008

62. Schmidt, T., \& Rammer, C. (2007). Non-technological and technological innovation: strange bedfellows? ZEWS Discussion Paper.

63. Schumpeter, J. A. (1934). The Theory of Economic Development: An Inquiry Into Profits, Capital, Credit, Interest, and the Business Cycle: Transaction Books.

64. Souto, J. E. (2015). Business model innovation and business concept innovation as the context of incremental innovation and radical innovation. Tourism Management, 51, 142-155. doi:10.1016/j.tourman.2015.05.017

65. Spieth, P., Schneckenberg, D., \& Ricart, J. E. (2014). Business model innovation - state of the art and future challenges for the field. $R \& D$ Management, 44(3), 237-247. doi:10.1111/ radm. 12071

66. Teece, D. J. (1986). Profiting from technological innovation: Implications for integration, collaboration, licensing and public policy. Research Policy, 15, 285-305.

67. Teece, D. J. (2010a). Business Models, Business Strategy and Innovation.
Long Range Planning, 43(2-3), 172194. doi:10.1016/j.lrp.2009.07.003

68. Teece, D. J. (2010b). Technological innovation and the theory of the firm: the role of enterprise-level knowledge, complementarities, and (dynamic) capabilities Handbook of the Economics of Innovation (Vol. 1, pp. 679-730): Elsevier.

69. Tongur, S., \& Engwall, M. (2014). The business model dilemma of technology shifts. Technovation, 34(9), 525535. doi:http://dx.doi.org/10.1016/j. technovation.2014.02.006

70. Tsai, K.-H., Liao, Y.-C., \& Hsu, T. T. (2015). Does the use of knowledge integration mechanisms enhance product innovativeness? Industrial Marketing Management, 46, 214-223. https://doi. org/10.1016/j.indmarman.2015.02.030

71. Turulja, L., \& Bajgorić, N. (2018). Innovation, firms' performance and environmental turbulence: is there a moderator or mediator? European Journal of Innovation Management. doi:doi. org/10.1108/EJIM-03-2018-0064

72. Visnjic, I., Wiengarten, F., \& Neely, A. (2016). Only the Brave: Product Innovation, Service Business Model Innovation, and Their Impact on Performance. Journal of Product Innovation Management, 33(1), 36-52. doi:10.1111/jpim.12254

73. Wei, Z., Yang, D., Sun, B., \& Gu, M. (2014). The fit between technological innovation and business model design for firm growth: evidence from China. $R \& D$ Management, 44(3), 288-305. doi:10.1111/radm.12069

74. Wernerfelt, B. (1984). A resourcebased view of the firm. Strategic Management Journal, 5(2), 171-180.

75. Wirtz, B., Göttel, V., \& Daiser, P. (2016). Business Model Innovation: 
Development, Concept and Future Research Directions. Journal of Business Models, 4(1).

76. Zott, C., \& Amit, R. (2007). Business Model Design and the Performance of Entrepreneurial Firms. Organization Science, 18(2), 181-199. doi: $10.2307 / 25146093$

77. Zott, C., \& Amit, R. (2008). The Fit between Product Market Strategy and Business Model: Implications for Firm Performance. Strategic
Management Journal, 29(1), 1-26. doi:10.2307/20141998

78. Zott, C., \& Amit, R. (2010). Business Model Design: An Activity System Perspective. Long Range Planning, 43(2-3), 216-226. doi:http://dx.doi. org/10.1016/j.lrp.2009.07.004

79. Zott, C., Amit, R., \& Massa, L. (2011). The Business Model: Recent Developments and Future Research. Journal of Management, 37(4), 1019-1042. doi:10.1177/0149206311406265

\section{MEĐUDJELOVANJE TEHNOLOŠKIH INOVACIJA I INOVACIJE POSLOVNOG MODELA USMJERENO NA OSTVARIVANJE PERFORMANSI}

Sažetak. U ovom se radu pokušava pojasniti odnos između tehnološke inovacije i inovacije poslovnog modela, kao i njihovog zajedničkog djelovanja na poslovni uspjeh srednjih i velikih poduzeća. Koristeći polazišta resursne teorije konkurentske prednosti, u ovom se radu izlaže sveobuhvatni istraživački model, koji analizira odnose između tehnološke inovacije i inovacija poslovnog modela, kao i njihov utjecaj na poslovni uspjeh. Za analizu podataka, prikupljenih u zemlji u razvoju, iz područja jugoistočne Europe, koristi se modeliranje strukturnih jednadžbi. Rezultati ukazuju da tehnološka inovacija ima pozitivan utjecaj na inovaciju poslovnog modela, koja pozitivno utječe na poslovni uspjeh poduzeća. Na kraju se potvrđuje medijacijski utjecaj inovacije poslovnog modela na povezanost između tehnološke inovacije i poslovnog uspjeha poduzeća. Znanstveni doprinos ovog istraživanja temelji se na empirijskoj analizi odnosa između tehnološke inovacije, inovacije poslovnog modela i poslovnog uspjeha poduzeća, pri čemu se utvrđuju utjecajni čimbenici u odnosu između tehnološke inovacije i inovacije poslovnog modela.

Ključne riječi: tehnološka inovacija, inovacija poslovnog modela, performanse poduzeća (poslovne performanse), resursna teorija konkurentske prednosti, modeliranje strukturnih jednadžbi 
